\title{
The Nexus Between Economic Freedom and Tourist Arrivals: Evidence from Mediterranean Countries
}

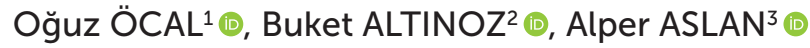

\begin{abstract}
Mediterranean countries are indispensable places of tourism with their world-famous shores, wonderful climate and impressive historical places. The aim of this paper is to investigate the relationship between tourist arrivals and economic freedom indicators such as government integrity, tax burden, government spending, business freedom and trade freedom. For this purpose, the panel vector autoregression (PVAR) method was used for a Mediterranean countries sample covering the period from 1996 to 2016. The results of causality testing showed that the tourist arrivals have a bidirectional causality relationship with each explanatory variable, while the coefficient estimates showed that an increase in economic freedom indices affected tourist arrivals negatively in Mediterranean countries. That is, economic freedoms do not mean an advantage for tourists without supportive public policies for tourism. The test results suggest that policymakers should take into account the various aspects of the tourism sector, particularly natural resources and environmental factors, while making policies that increase economic freedom in Mediterranean countries.
\end{abstract}

Keywords: Tourism, Economic freedom, Panel VAR, Causality JEL Classification: B22, C23, L83

\author{
${ }^{1}$ Assoc. Prof., Kayseri University, Faculty of \\ Applied Sciences, Kayseri, Turkey \\ ${ }^{2}$ Lecturer, Nisantasi University, İstanbul, Turkey \\ ${ }^{3}$ Prof. Dr., Erciyes University, Department of \\ Aviation Management, Kayseri, Turkey \\ ORCID: O.Ö. 0000-0002-4276-4821; \\ B.A. $0000-0003-1408-0921$; \\ A.A. $0000-0002-5729-7218$

\section{Corresponding author:} \\ Alper ASLAN, \\ Erciyes University, Department of Aviation \\ Management, Kayseri, Turkey \\ E-mail: alperaslan@erciyes.edu.tr
}

Submitted: 13.11 .2020

Accepted: 08.12.2020

Citation: Ocal, O., Altinoz, B., \& Aslan, A.

(2020). The nexus between economic freedom and tourist arrivals: evidence from

mediterranean countries. Istanbul iktisat Dergisi - Istanbul Journal of Economics, 70(2), 287-301.

https://doi.org/10.26650/ISTJECON2020-825490 


\section{Introduction}

The tourism sector is the focus of attention in both developed and developing countries because it is the fastest growing sector in the world. Also, countries focus on the tourism sector development in terms of both contributing to growth through the production of goods and services as well as providing significant employment opportunities. There are a number of studies (Samimi, Sadeghi and Sadeghi, 2011; Aslan, 2014; Lean, Chong and Hooy, 2014; Aslan, 2016; etc.) in the literature that reveal that developments in the tourism sector contribute to the economic growth of countries. Given the fact that economic growth is the main macroeconomic target of countries, it can be considered a necessity to identify the key dynamics that contribute to the development of the tourism sector and the importance of international tourism. Determining the factors that determine the international tourism demand in particular, provides the shaping of the policies for the development of the sector. In this context, studies on the contribution of freedoms to the tourism sector development have a critical importance in the literature (Gholipour, Tajaddini and Al-Mulali, 2014; Kubickova, 2016; Saha, Su and Campbell, 2017; Özcan, Aslan and Nazlığlu, 2017).

Economic freedom is a concept that evokes the liberal economic system and has been discussed almost since the classical economics period. It implies that individuals are free to make decisions in many economic activities and that their economic rights are guaranteed by law. Economic freedom can be divided into four groups: the rule of law, the size of the government, the efficiency of regulation and market openness. Among them, property rights, judicial efficiency and the integrity of the state are evaluated within the framework of the rule of law. Examples of indicators of size of a government include tax burden, financial freedom and government spending. In addition, while the scope of a firm's freedom, labour freedoms and efficiency of monetary liberty regulations are assessed; trade openness, investment liberalization and financial liberalization are included in the market openness (Miller and Kim, 2017, p. 20). Given the conceptually economic freedom and its basic components, the relationship between economic freedom and the tourism sector is in fact an expression of the 
effect of the state's economic position and economic liberalization on international tourism demand.

The effect of institutional factors such as economic freedom on the inbound tourism has relatively limited literature. Gholipour et al. (2014) investigated the effects of individual freedoms on outbound tourism, but they neglect inbound tourism. In this study, which is based on the data of 80 countries in the 1999-2011 period, it is observed that lower level individual freedom increases outbound tourism. Su and Lin (2014) used a freedom index derived from political rights and civil liberties as a control variable in their study of inbound tourism and their results reveal that freedom affects tourism demand. However, what is important here is that freedoms in their study are not seen as the main factors influencing tourism demand. Kubickova (2016) investigated the impact of economic freedom on tourism sector competitiveness, but this study reached statistically insignificant effect. Özcan et al. (2017) examine the relationship between economic freedom and tourist arrivals for 17 post-communist countries. According to their findings there is no bidirectional causality between economic freedom and tourist arrivals. Additionally, (Saha et al., 2017) explored the importance of economic and political freedom for inbound tourism. Findings from 110 countries using data from 1995 to 2012 reveal that economic and political freedoms have a positive impact on inbound tourism.

The aim of this paper is to contribute to the current literature by investigating the effect of economic freedom on tourist arrivals for Mediterranean countries. It can be said that tourists are not interested in whether the economy of the country is liberal in their decision to visit a country. But in a country with a high level of economic freedom, it can be said that the quality of tourism services is better due to the entrepreneurial activities and thus the increasing competition environment (Saha et al, 2017). An increase in entrepreneurial activities means more tourist businesses. On the other hand, the influences of each component of economic freedom on inbound tourism may be different. In particular, government spending that provides information on the size of the government is one of these components, and the positive relationship between public expenditures and the 
size of the government is generally accepted. Tax burden and business freedom can be linked to the widespread use of entrepreneurial activities. In addition to these, freedom of trade is an important factor, contributing to diversity of goods and services and thus increasing the level of satisfaction of tourists coming to the country. Therefore, another important contribution of the study is to prioritize the factors that can be directly related to the tourism sector within the economic freedom indicators. Also, the panel VAR method is used in this paper provides strong evidence for the relationship since it is an appropriate method to analyze the transmission of shocks that may occur at panel (Canova and Ciccarelli, 2013). In summary, the contribution of this paper to academic literature is to fill the gaps in the related literature, to emphasize the importance of economic freedom components in terms of the tourism sector and to provide strong evidence with the used method.

The rest of the paper is constructed as follows: The next section describes the dataset and explains econometric methodology. Later empirical findings are reported. Finally, in the last section, findings obtained from the analysis are presented and a set of policy proposals are presented.

\section{Data and Methodology}

In this paper, it is investigated the relationship between indicators of economic freedom and tourist arrivals in 17 Mediterranean countries, using yearly dataset for the period from 1996 to 2016. These countries are: Albania, Bosnia and Herzegovina, Croatia, Cyprus, Egypt, France, Greece, Israel, Italy, Lebanon, Malta, Morocco, Slovenia, Spain, Tunisia and Turkey. The dependent variable of the paper is tourist arrivals, which express the number of foreign tourists coming to each country and this variable was obtained from the World Bank database. The government integrity, tax burden, government expenditures, business freedom and trade freedom variables are used as indicators of economic freedom. These variables, calculated by the Heritage Foundation, have values between 0 and 100, which means that as it approaches 100 , freedom increases. All variables are logarithmically analyzed. 
The stability of the series is analyzed before the relationship between economic freedom and tourist arrivals is tested. Primarily the Levin, Lin and Chu (LLC) (2002) unit root test is applied. A basic LLC unit root test model is estimated as:

$$
\Delta \gamma_{i t}=\beta_{i}+\delta \gamma_{i t-1}+\sum_{k=1}^{Z} \rho_{k} \Delta \gamma_{i t-k}+\theta_{i t}+\vartheta_{t}+\mu_{i t}
$$

In the equation, $\Delta$ is the first difference operator, $z$ is the delay length, finally $\beta$ and $\vartheta$ is the respectively unit-specific constant and time effects. In the LLC unit root test, it is assumed that the $\delta$ coefficient is homogeneous for all units. In the IPS unit root test, heterogeneity is allowed by stretching the homogeneity between the units. The basic model for the IPS test procedure is established as follows (Im, Pesaran and Shin, 2003):

$$
\Delta Y_{i t}=\delta Y_{i t-1}+\sum_{j=1}^{z_{i}} \theta_{i j} \Delta Y_{i t-j}+X_{i t}^{\prime} \emptyset+\mu_{i t}
$$

In this paper we use the Panel VAR method to examine the relationship between economic freedom and tourist arrivals. It is generally assumed that all variables in VAR models are endogenous and interdependent and the panel VAR model consists of a combination of traditional VAR method and panel data models (Canova and Ciccarelli, 2013). A basic panel VAR equation can be written as follows (Abrigo and Love, 2015):

$$
Y_{i t}=Y_{i t-1} A_{1}+Y_{i t-2} A_{2}+\cdots+Y_{i t-p} A_{p-1}+Y_{i t-p} A_{P}+X_{i t} B+u_{i t}+e_{i t}
$$

where $Y_{i t}$ is $(k x k)$ vector of independent variables, $X_{i t}$ is $(1 \mathrm{xl})$ vector of exogenous covariates and $u_{i}$ and $e_{i t}$ are vectors of dependent variable-specific panel fixedeffects and idiosyncratic errors respectively.

There are a number of econometric advantages within the panel VAR method. This method is effective in analyzing the transmission of shocks that may occur in panel. Panel VAR models are suitable for creating average effects in groups of no non-homogeneous units and analyzing specific differences relative to the mean. The panel VAR method can also be used to analyze the importance of 
interdependencies and to check whether feedback is generalized (Canova and Ciccarelli, 2013). Panel VAR analysis structurally contains three techniques, namely Granger causality analysis, impact-response analyses and variance decomposition.

The causality test is a simple application of (Granger, 1969) to heterogeneous panel data models. The basic model for panel causality is constructed as follows:

$$
y_{i t}=\delta_{i}+\sum_{n=1}^{N} \gamma_{i}^{(n)} y_{i t-n}+\sum_{n=1}^{N} \beta_{i}^{(n)} x_{i t-n}+\varepsilon_{i t}
$$

where $x$ and $y$ are stationary variables for $t$ periods and $i$ units. In this test, it is assumed that the individual effects are fixed and the lag-order $(N)$ is to be common. While $\gamma_{i}^{(n)}$ expresses the autoregressive parameters, $\beta_{i}^{(n)}$ denotes slope coefficients. If the past values of the variable $x$ observed on the unit $i$ improve the forecasts of the variable $y$ for this unit $i$; then it can be said that $x$ causes $y$.

\section{Empirical Results}

This section contains the results of an analysis to test the hypothesis that economic freedom affects the arrival of tourists. First, it is tested whether the series are stationary by using the Levin, Lin and Chu (2002) with Im, Pesaran and Shin (2003) panel unit root tests. The panel unit root test results are presented in Table 1 below:

Table 1: Panel Unit Root Tests

\begin{tabular}{|l|c|c|c|c|}
\hline & \multicolumn{2}{|c|}{ LLC } & \multicolumn{2}{c|}{ IPS } \\
\hline Variable & Level & First Difference & Level & First Difference \\
\hline log_trst & $5.332(1.000)$ & $-9.980^{*}(0.000)$ & $2.125(0.983)$ & $-9.312^{*}(0.000)$ \\
\hline log_bus & $0.523(0.300)$ & $-32.036^{*}(0.000)$ & $-5.275^{*}(0.000)$ & $-12.104^{*}(0.000)$ \\
\hline log_gov & $0.249(0.401)$ & $-13.745^{*}(0.000)$ & $-0.900(0.184)$ & $-7.464^{*}(0.000)$ \\
\hline log_govint & $0.168(0.566)$ & $-21.791^{*}(0.000)$ & $-5.260^{*}(0.000)$ & $-13.352^{*}(0.000)$ \\
\hline log_tax & $2.310(0.989)$ & $-46.342^{*}(0.000)$ & $-11.595^{*}(0.000)$ & $-18.396^{*}(0.000)$ \\
log_trade & $3.607(0.999)$ & $-67.945^{*}(0.000)$ & $-11.112^{*}(0.000)$ & $-26.914^{*}(0.000)$ \\
\hline
\end{tabular}

Note: * denotes $1 \%$ statistically significance level. 
The LLC unit root test show that the first differences of all series are stable when received, while the IPS test show that only log_trst and log_gov are stable at the level of the series.

Table 2: Panel VAR Lag Length Selection Criteria

\begin{tabular}{|l|c|c|c|c|c|c|}
\hline Lag & CD & J & J p-value & MBIC & MAIC & MQIC \\
\hline 1 & 0.999968 & 103.2741 & 0.610577 & -501.7547 & -112.7259 & -268.9252 \\
\hline 2 & 0.999988 & 61.66967 & 0.802220 & -341.6829 & -82.33033 & -186.4632 \\
\hline 3 & 0.721247 & 32.54821 & 0.633548 & -169.1281 & -39.45179 & -91.51822 \\
\hline
\end{tabular}

Note: Optimal lag length is 1 .

After the unit root tests are performed, the second step is selecting lag length selection criteria. When Table 2 is examined, it can be see that first-order panel VAR is the preferred model, since this has the smallest MBIC, MAIC and MQIC. In the next stage, the panel VAR method is applied using GMM style estimation according to optimal lag (1). Panel estimation results based on the GMM approach are given in Table 3 .

Table 3: Estimation VAR Results (GMM), lag (1)

\begin{tabular}{|l|c|c|c|c|c|}
\hline Dep. Var & Indep. Var. & Coef. & S.E & Z & P. Value \\
\hline log_trst & log_trst & -0.122 & 0.017 & -7.04 & 0.000 \\
\hline log_trst & log_govint & -0.973 & 0.147 & -6.62 & 0.000 \\
\hline log_trst & log_tax & 4.890 & 0.384 & 12.73 & 0.000 \\
\hline log_trst & log_gov & -0.368 & 0.027 & -13.53 & 0.000 \\
\hline log_trst & log_bus & -4.060 & 0.340 & -11.91 & 0.000 \\
log_trst & log_trade & -1.052 & 0.208 & -5.05 & 0.000 \\
\hline log_govint & log_trst & 0.156 & 0.005 & 29.15 & 0.000 \\
\hline log_govint & log_govint & -0.319 & 0.065 & -4.88 & 0.000 \\
\hline log_govint & log_tax & 2.125 & 0.161 & 13.20 & 0.000 \\
\hline log_govint & log_gov & 0.033 & 0.011 & -2.86 & 0.004 \\
\hline log_govint & log_bus & -1.917 & 0.160 & -11.93 & 0.000 \\
log_govint & log_trade & -0.418 & 0.092 & -4.51 & 0.000 \\
\hline log_tax & log_trst & 0.288 & 0.012 & 23.87 & 0.000 \\
\hline log_tax & log_govint & -0.610 & 0.085 & -7.15 & 0.000 \\
\hline log_tax & log_tax & 3.205 & 0.214 & 14.92 & 0.000 \\
\hline log_tax & log_gov & -0.128 & 0.016 & -8.01 & 0.000 \\
\hline log_tax & log_bus & -2.810 & 0.199 & -14.06 & 0.000 \\
log_tax & log_trade & -0.597 & 0.108 & -5.49 & 0.000 \\
\hline log_gov & log_trst & 0.184 & 0.007 & 24.06 & 0.000 \\
\hline
\end{tabular}




\begin{tabular}{|l|c|c|c|c|c|}
\hline log_gov & log_govint & -0.616 & 0.089 & -6.92 & 0.000 \\
\hline log_gov & log_tax & 1.261 & 0.168 & 7.48 & 0.000 \\
\hline log_gov & log_gov & -0.236 & 0.032 & -7.26 & 0.000 \\
\hline log_gov & log_bus & -2.468 & 0.228 & -10.81 & 0.000 \\
log_gov & log_trade & 1.336 & 0.194 & 6.88 & 0.000 \\
\hline log_bus & log_trst & 0.242 & 0.010 & 23.49 & 0.000 \\
\hline log_bus & log_govint & -0.432 & 0.070 & -6.14 & 0.000 \\
\hline log_bus & log_tax & 2.796 & 0.185 & 15.08 & 0.000 \\
\hline log_bus & log_gov & -0.106 & 0.013 & -7.88 & 0.000 \\
\hline log_bus & log_bus & -2.329 & 0.171 & -13.59 & 0.000 \\
log_bus & log_trade & -0.692 & 0.095 & -7.22 & 0.000 \\
\hline log_trade & log_trst & 0.271 & 0.012 & 21.48 & 0.000 \\
\hline log_trade & log_govint & -0.552 & 0.080 & -6.85 & 0.000 \\
\hline log_trade & log_tax & 2.956 & 0.198 & 14.87 & 0.000 \\
\hline log_trade & log_gov & -0.119 & 0.015 & -7.93 & 0.000 \\
\hline log_trade & log_bus & -2.354 & 0.182 & -12.91 & 0.000 \\
\hline log_trade & log_trade & -0.766 & 0.102 & -7.49 & 0.000 \\
\hline
\end{tabular}

Note: All probability values in the table have a $1 \%$ statistical significance level.

The estimation results for tourist arrivals show that government integrity, tax burden, government spending, business freedom and trade freedom are statistically significant, but unexpected signs at least for business freedom and trade freedom. This result can be interpreted as a consequence of the increase in business freedom and trade freedom, which tends to consume its natural resources by turning to the industrial sector of the countries.

Table 4: Panel VAR Granger Causality Wald Test Results

\begin{tabular}{|l|c|c|c|c|}
\hline Equation & Excluded & Chi2 & df & Prob>Chi2 \\
\hline log_trst & log_govint & 43.850 & 1 & 0.000 \\
\hline log_trst & log_tax & 162.095 & 1 & 0.000 \\
\hline log_trst & log_gov & 183.089 & 1 & 0.000 \\
\hline log_trst & log_bus & 141.873 & 1 & 0.000 \\
\hline log_trst & log_trade & 25.536 & 1 & 0.000 \\
log_trst & ALL & 342.829 & 5 & 0.000 \\
\hline log_govint & log_trst & 849.613 & 1 & 0.000 \\
\hline log_govint & log_tax & 174.132 & 1 & 0.000 \\
\hline log_govint & log_gov & 8.161 & 1 & 0.004 \\
\hline log_govint & log_bus & 142.419 & 1 & 0.000 \\
\hline log_govint & log_trade & 20.345 & 1 & 0.000 \\
log_govint & ALL & 1146.716 & 5 & 0.000 \\
\hline log_tax & log_trst & 569.794 & 1 & 0.000 \\
\hline
\end{tabular}




\begin{tabular}{|c|c|c|c|c|}
\hline log_tax & log_govint & 51.076 & 1 & 0.000 \\
\hline log_tax & log_gov & 64.133 & 1 & 0.000 \\
\hline log_tax & log_bus & 197.548 & 1 & 0.000 \\
\hline log_tax & log_trade & 30.154 & 1 & 0.000 \\
\hline log_tax & ALL & 809.071 & 5 & 0.000 \\
\hline log_gov & log_trst & 578.879 & 1 & 0.000 \\
\hline log_gov & log_govint & 47.858 & 1 & 0.000 \\
\hline log_gov & log_tax & 55.911 & 1 & 0.000 \\
\hline log_gov & log_bus & 116.899 & 1 & 0.000 \\
\hline log_gov & log_trade & 47.323 & 1 & 0.000 \\
\hline log_gov & ALL & 747.367 & 5 & 0.000 \\
\hline log_bus & log_trst & 551.606 & 1 & 0.000 \\
\hline log_bus & log_govint & 37.760 & 1 & 0.000 \\
\hline log_bus & log_tax & 227.405 & 1 & 0.000 \\
\hline log_bus & log_gov & 62.081 & 1 & 0.000 \\
\hline log_bus & log_trade & 52.099 & 1 & 0.000 \\
\hline log_bus & ALL & 900.820 & 5 & 0.000 \\
\hline log_trade & log_trst & 461.327 & 1 & 0.000 \\
\hline log_trade & log_govint & 46.940 & 1 & 0.000 \\
\hline log_trade & log_tax & 221.204 & 1 & 0.000 \\
\hline log_trade & log_gov & 62.811 & 1 & 0.000 \\
\hline log_trade & log_bus & 166.747 & 1 & 0.000 \\
\hline log_trade & ALL & 792.182 & 5 & 0.000 \\
\hline
\end{tabular}

Note: All probability values in the table have a $1 \%$ statistical significance level.

The next step is employing the panel VAR Granger causality test, and the test results are presented in Table 4. The results show that there is a bi-directional causality between all dependent and independent variables. 
Figure 1. Roots of Companion Matrix

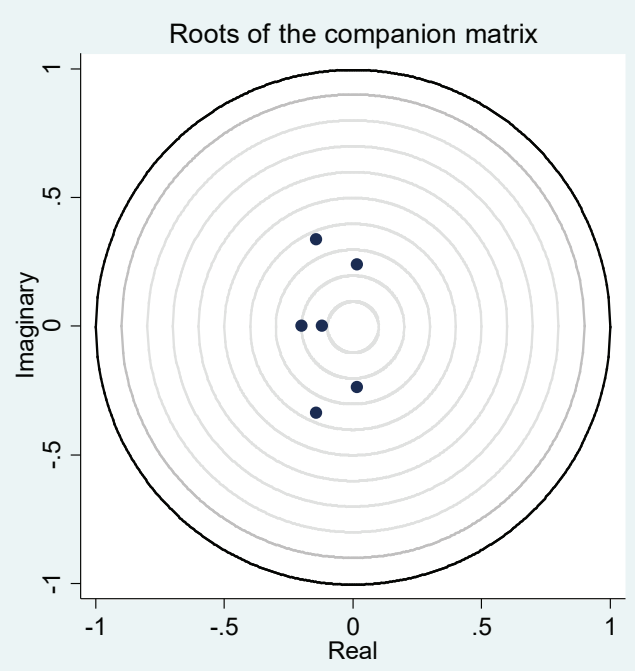

After estimating the coefficient and investigating the causality, the stability condition is checked. The resulting graph of eigenvalues above confirms that the estimate is stable. The stability of the long run coefficient estimation results demonstrates that the model is suitable for obtaining short run impulse-response functions and analyzing variance decomposition. After the stability condition is achieved, the next stage of the analysis is passed. 
Figure 2. Impulse-Response Graph

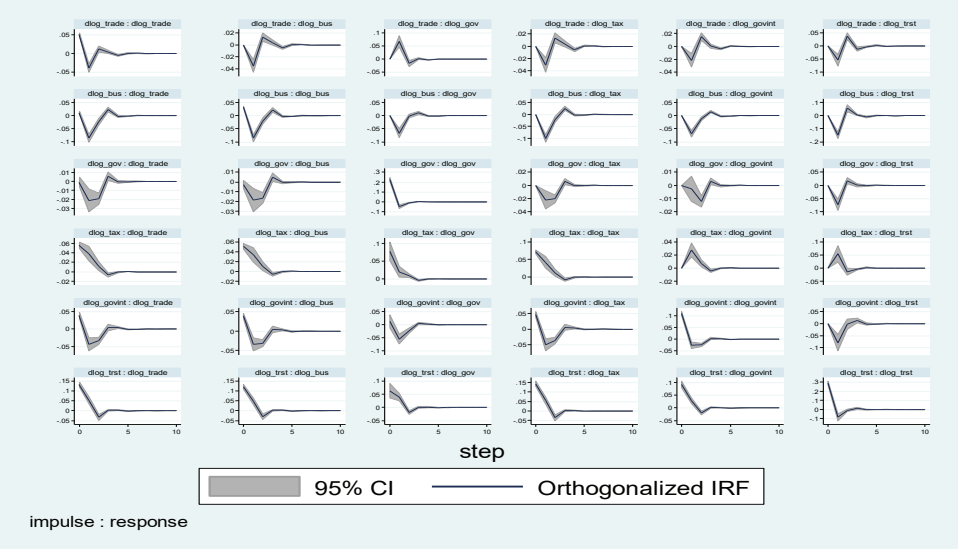

According to the impulse response graphs presented in Figure 2 above, an impulse, in terms of increased economic freedom, to the trade freedom, business freedom, government spending and government integrity variables reduces tourist arrivals in the short run. Another important component of the analysis is variance research. Variance decomposition results imply that how much percentage of the changes in the dependent variable resulted from the independent variables. When Table 5 is examined, the variation of tourist arrivals is explained about $4 \%$ by government integrity, about $2 \%$ by tax burden, about $4 \%$ by government spending, about $18 \%$ by business freedom, about $3 \%$ by trade freedom and about $67 \%$ by own. This result show that the arrival of tourists is influenced by the own past experiences rather than by changes in economic freedoms.

Table 5: Variance Decomposition

\begin{tabular}{|l|c|c|c|c|c|c|}
\hline \multicolumn{7}{|l|}{ Impulse Response to Tourist Arrivals } \\
\hline Horizon & log_trst & log_govint & log_tax & log_gov & log_bus & log_trade \\
\hline 0 & 0 & 0 & 0 & 0 & 0 & 0 \\
\hline 1 & 1 & 0 & 0 & 0 & 0 & 0 \\
\hline 2 & 0.700 & 0.048 & 0.022 & 0.041 & 0.165 & 0.022 \\
\hline 3 & 0.673 & 0.046 & 0.023 & 0.042 & 0.182 & 0.031 \\
\hline 4 & 0.672 & 0.047 & 0.023 & 0.041 & 0.182 & 0.032 \\
\hline 5 & 0.672 & 0.047 & 0.023 & 0.041 & 0.182 & 0.032 \\
\hline
\end{tabular}




\begin{tabular}{|l|l|l|l|l|l|l|}
\hline 6 & 0.671 & 0.047 & 0.023 & 0.041 & 0.182 & 0.032 \\
\hline 7 & 0.671 & 0.047 & 0.023 & 0.041 & 0.182 & 0.032 \\
\hline 8 & 0.671 & 0.047 & 0.023 & 0.041 & 0.183 & 0.032 \\
\hline 9 & 0.671 & 0.047 & 0.023 & 0.041 & 0.183 & 0.032 \\
\hline 10 & 0.671 & 0.047 & 0.023 & 0.041 & 0.183 & 0.032 \\
\hline
\end{tabular}

Impulse Response to Government Integrity

\begin{tabular}{|l|c|c|c|c|c|c|}
\hline Horizon & log_trst & log_govint & log_tax & log_gov & log_bus & log_trade \\
\hline 0 & 0 & 0 & 0 & 0 & 0 & 0 \\
\hline 1 & 0.417 & 0.582 & 0 & 0 & 0 & 0 \\
\hline 2 & 0.336 & 0.452 & 0.027 & 0.000 & 0.167 & 0.016 \\
\hline 3 & 0.331 & 0.448 & 0.028 & 0.005 & 0.163 & 0.023 \\
\hline 4 & 0.328 & 0.444 & 0.028 & 0.005 & 0.169 & 0.023 \\
\hline 5 & 0.328 & 0.444 & 0.028 & 0.005 & 0.169 & 0.023 \\
\hline 6 & 0.328 & 0.444 & 0.028 & 0.005 & 0.169 & 0.023 \\
\hline 7 & 0.328 & 0.444 & 0.028 & 0.005 & 0.169 & 0.023 \\
\hline 8 & 0.328 & 0.444 & 0.028 & 0.005 & 0.169 & 0.023 \\
\hline 9 & 0.328 & 0.444 & 0.028 & 0.005 & 0.169 & 0.023 \\
\hline 10 & 0.328 & 0.444 & 0.028 & 0.005 & 0.169 & 0.023 \\
\hline
\end{tabular}

Impulse Response to Tax Burden

\begin{tabular}{|l|c|c|c|c|c|c|}
\hline Horizon & log_trst & log_govint & log_tax & log_gov & log_bus & log_trade \\
\hline 0 & 0 & 0 & 0 & 0 & 0 & 0 \\
\hline 1 & 0.737 & 0.079 & 0.183 & 0 & 0 & 0 \\
\hline 2 & 0.506 & 0.100 & 0.147 & 0.010 & 0.215 & 0.019 \\
\hline 3 & 0.492 & 0.119 & 0.139 & 0.017 & 0.207 & 0.022 \\
\hline 4 & 0.485 & 0.118 & 0.138 & 0.018 & 0.217 & 0.021 \\
\hline 5 & 0.484 & 0.118 & 0.137 & 0.018 & 0.217 & 0.022 \\
\hline 6 & 0.484 & 0.118 & 0.137 & 0.018 & 0.217 & 0.022 \\
\hline 7 & 0.484 & 0.118 & 0.137 & 0.018 & 0.217 & 0.022 \\
\hline 8 & 0.484 & 0.118 & 0.137 & 0.018 & 0.217 & 0.022 \\
\hline 9 & 0.484 & 0.118 & 0.137 & 0.018 & 0.217 & 0.022 \\
\hline 10 & 0.484 & 0.118 & 0.137 & 0.018 & 0.217 & 0.022 \\
\hline
\end{tabular}

Impulse Response to Government Spending

\begin{tabular}{|l|c|c|c|c|c|c|}
\hline Horizon & log_trst & log_govint & log_tax & log_gov & log_bus & log_trade \\
\hline 0 & 0 & 0 & 0 & 0 & 0 & 0 \\
\hline 1 & 0.064 & 0.002 & 0.098 & 0.834 & 0 & 0 \\
\hline 2 & 0.071 & 0.039 & 0.083 & 0.691 & 0.055 & 0.058 \\
\hline 3 & 0.074 & 0.045 & 0.082 & 0.681 & 0.549 & 0.061 \\
\hline 4 & 0.074 & 0.045 & 0.082 & 0.680 & 0.056 & 0.060 \\
\hline 5 & 0.074 & 0.045 & 0.082 & 0.680 & 0.056 & 0.061 \\
\hline 6 & 0.074 & 0.045 & 0.082 & 0.680 & 0.056 & 0.061 \\
\hline 7 & 0.074 & 0.045 & 0.082 & 0.680 & 0.056 & 0.061 \\
\hline 8 & 0.074 & 0.045 & 0.082 & 0.680 & 0.056 & 0.061 \\
\hline 9 & 0.074 & 0.045 & 0.082 & 0.680 & 0.056 & 0.061 \\
\hline 10 & 0.074 & 0.045 & 0.082 & 0.680 & 0.056 & 0.061 \\
\hline
\end{tabular}




\begin{tabular}{|l|c|c|c|c|c|c|}
\hline \multicolumn{6}{|l|}{ Impulse Response to Business Freedom } \\
\hline Horizon & log_trst & log_govint & log_tax & log_gov & log_bus & log_trade \\
\hline 0 & 0 & 0 & 0 & 0 & 0 & 0 \\
\hline 1 & 0.740 & 0.747 & 0.129 & 0.000 & 0.054 & 0 \\
\hline 2 & 0.511 & 0.079 & 0.111 & 0.010 & 0.249 & 0.037 \\
\hline 3 & 0.496 & 0.100 & 0.106 & 0.016 & 0.241 & 0.038 \\
\hline 4 & 0.488 & 0.099 & 0.105 & 0.017 & 0.251 & 0.038 \\
\hline 5 & 0.488 & 0.099 & 0.105 & 0.017 & 0.250 & 0.039 \\
\hline 6 & 0.488 & 0.099 & 0.105 & 0.017 & 0.250 & 0.039 \\
\hline 7 & 0.488 & 0.099 & 0.105 & 0.017 & 0.250 & 0.039 \\
\hline 8 & 0.488 & 0.099 & 0.105 & 0.017 & 0.250 & 0.039 \\
\hline 9 & 0.488 & 0.099 & 0.105 & 0.017 & 0.250 & 0.039 \\
\hline 10 & 0.488 & 0.099 & 0.105 & 0.017 & 0.250 & 0.039 \\
\hline Impulse Response to Trade Freedom & \multicolumn{5}{|l}{} \\
\hline Horizon & log_trst & log_govint & log_tax & log_gov & log_bus & log_trade \\
\hline 0 & 0 & 0 & 0 & 0 & 0 & 0 \\
\hline 1 & 0.707 & 0.060 & 0.123 & 0.000 & 0.005 & 0.102 \\
\hline 2 & 0.505 & 0.083 & 0.112 & 0.010 & 0.187 & 0.099 \\
\hline 3 & 0.491 & 0.102 & 0.107 & 0.017 & 0.184 & 0.095 \\
\hline 4 & 0.484 & 0.101 & 0.106 & 0.018 & 0.194 & 0.094 \\
\hline 5 & 0.484 & 0.101 & 0.106 & 0.018 & 0.194 & 0.095 \\
\hline 6 & 0.483 & 0.101 & 0.106 & 0.018 & 0.194 & 0.095 \\
\hline 7 & 0.483 & 0.101 & 0.106 & 0.018 & 0.194 & 0.095 \\
\hline 8 & 0.483 & 0.101 & 0.106 & 0.018 & 0.194 & 0.095 \\
\hline 9 & 0.483 & 0.101 & 0.106 & 0.018 & 0.194 & 0.095 \\
\hline 10 & 0.483 & 0.101 & 0.106 & 0.018 & 0.194 & 0.095 \\
\hline
\end{tabular}

\section{Conclusion}

In this study, the effect of economic freedoms on tourist arrivals is explored for Mediterranean countries by using the panel VAR method. The results of the study are important due to the fact that the literature on the issue is very limited and because of the critical value of the tourism sector globally. Government integrity, tax burden, government spending, business freedom and trade freedom are used as explanatory variables to investigate the relationship between tourist arrivals and economic freedom.

When we take into account that all the economic freedom indicators have a value between 0 and 100 and that as the value approaches 100, the freedoms 
increase, the results show that the increase in freedoms negatively affects tourist arrivals in Mediterranean countries (this result is inconsistent with the results of (Saha et al., 2017). The concept of economic freedom implies that the state's share in the economy s smaller compared to the private sector. As a matter of fact, when the rate of the state in the economy is reduced, or when the government is involved in activities to support the private sector, the emerging competitive environment will turn into a structure driven by the profit motive. According to test results such an environment does not result in favour of tourism in Mediterranean countries, which are mostly composed of developing countries. On the other hand, the results of the causality test show that all variables are in a bidirectional causality relationship with each other (this result is inconsistent with the results of (Özcan et al. 2017).

As a result, at first glance, the assumption that the increase in economic freedoms, will affect the tourist arrivals positively seems to suggest that, in fact, economic freedoms do not mean an advantage for tourists without the supportive policies of the tourism. The task of the government is, at the very least, to implement policies that are least harmful to natural resources in a competitive environment emerging with freedoms.

Peer-review: Externally peer-reviewed.

Conflict of Interest: The authors have no conflict of interest to declare.

Grant Support: The authors declared that this study has received no financial support.

\section{References}

Abrigo, M. R. M. \& Love, I. (2015). Estimation of panel vector autoregressive in stata: A package of programs. Retrieved from http://paneldataconference2015.ceu.hu/Program/Michael-Abrigo. pdf.

Aslan, A. (2014). Tourism development and economic growth in the Mediterranean countries: Evidence from panel Granger causality tests. Current Issues in Tourism, 17(4), 363-372. https:// doi.org/10.1080/13683500.2013.768607

Aslan, A. (2016). Does tourism cause growth: evidence from Turkey. Current Issues in Tourism, 19(12), 1176-1184. https://doi.org/10.1080/13683500.2015.1015970

Canova, C. \& Ciccarelli, M. (2013). Panel vector autoregressive models: A survey. European Central Bank Working Paper Series, No: 1507. Retrieved from https://www.ecb.europa.eu/pub/pdf/ scpwps/ecbwp1507.pdf. 
Enders, W. (1995). Applied econometrics time series. New York: Johnwiley and Song Inc.

Gholipour, H. F., Tajaddini, R. \& Al-Mulali, R. (2014). Does personal freedom influence outbound tourism?. Tourism Management, 41, 19-25. https://doi.org/10.1016/j.tourman.2013.08.010

Granger, C. W. J. (1969). Investigating causal relations by econometric models and cross-spectral methods. Econometrica, 37(3), 424-438. Retrieved from https://www.jstor.org/ stable/1912791?seq=15\#metadata_info_tab_contents

Im, K. S., Pesaran, M. \& Shin, Y. (2003). Testing for unit roots in heterogeneous panels. Journal of Econometrics, 115(1), 53-74. https://doi.org/10.1016/S0304-4076(03)00092-7

Kubickova, M. (2016). The role of government in tourism: Linking competitiveness, freedom, and developing economies. Czech Journal of Tourism, 5(2), 79-92. http://doi.org/10.1515/cjot-20160005

Lean, H. H., Chong, S. H. \& Hooy, C. W. (2014). Tourism and economic growth: Comparing Malaysia and Singapore. International Journal of Economics and Management, 8(1), 139-157. Retrieved from file:///C:/Users/Casper/Downloads/IJEM2014-hooi-tourism.pdf

Levin, A., C.-F. Lin, \& C.-S. J. Chu. 2002. Unit root tests in panel data: Asymptotic and finite-sample properties. Journal of Econometrics, 108, 1-24.

Özcan, C. C., Aslan, M., \& Nazlıoğlu, S. (2017). Economic freedom, economic growth and international tourism for post-communist (transition) countries: A panel causality analysis. Theoretical and Applied Economics, 24(2), 75-98. Retrieved from http://store.ectap.ro/ articole/1270.pdf

Saha, S., Su, J-J. \& Campbell, N. (2017). Does political and economic freedom matter for inbound tourism? A cross-national panel data estimation. Journal of Travel Research, 56(2). https://doi. org/10.1177/0047287515627028

Samimi, A. J., Sadeghi, S. \& Sadeghi, S. (2011). Tourism and economic growth in developing countries: P-VAR approach. Middle-East Journal of Scientific Research, 10(1), 28-32. Retrieved from http://www.idosi.org/mejsr/mejsr10(1)11/5.pdf 
